\title{
Giant Cell Tumor of Bone
}

\author{
Risk Factors for Recurrence
}

\author{
Frank M. Klenke MD, PhD, Doris E. Wenger MD, \\ Carrie Y. Inwards MD, Peter S. Rose MD, \\ Franklin H. Sim MD
}

Received: 23 December 2009/Accepted: 21 July 2010/Published online: 13 August 2010

(C) The Association of Bone and Joint Surgeons (B) 2010

\begin{abstract}
Background Many surgeons treat giant cell tumor of bone (GCT) with intralesional curettage. Wide resection is reserved for extensive bone destruction where joint preservation is impossible or when expendable sites (eg, fibular head) are affected. Adjuvants such as polymethylmethacrylate and phenol have been recommended to reduce the risk of local recurrence after intralesional surgery. However, the best treatment of these tumors and risk factors for recurrence remain controversial.

Questions/purposes We evaluated the recurrence-free survival after surgical treatment of GCT to determine the influence of the surgical approach, adjuvant treatment, local tumor presentation, and demographic factors on the risk of recurrence.

Methods We retrospectively reviewed 118 patients treated for benign GCT of bone between 1985 and 2005. Recurrence rates, risk factors for recurrence and the development

Each author certifies that he or she has no commercial associations (eg, consultancies, stock ownership, equity interest, patent/licensing arrangements, etc) that might pose a conflict of interest in connection with the submitted article.

Each author certifies that his or her institution has approved the human protocol for this investigation and that all investigations were conducted in conformity with ethical principles of research.
\end{abstract}

F. M. Klenke, P. S. Rose, F. H. Sim ( $\square)$

Department of Orthopedic Surgery, Mayo Clinic, 200 First Street

SW, Rochester, MN 55905, USA

e-mail: sim.franklin@mayo.edu

D. E. Wenger

Department of Radiology, Mayo Clinic, Rochester, MN, USA

C. Y. Inwards

Department of Laboratory Medicine and Pathology, Mayo

Clinic, Rochester, MN, USA of pulmonary metastases were determined. The minimum followup was 36 months (mean, $108.4 \pm 43.7$; range, 36-233 months).

Results Wide resection had a lower recurrence rate than intralesional surgery (5\% versus 25\%). Application of polymethylmethacrylate decreased the risk of local recurrence after intralesional surgery compared with bone grafting; phenol application alone had no effect on the risk of recurrence. Pulmonary metastases occurred in 4\%; multidisciplinary treatment including wedge resection, chemotherapy, and radiotherapy achieved disease-free survival or stable disease in all of these patients.

Conclusion We recommend intralesional surgery with polymethylmethacrylate for the majority of primary GCTs. Because pulmonary metastases are rare and aggressive treatment of pulmonary metastases is usually successful, we believe the potential for metastases should not by itself create an indication for wide resection of primary tumors. Level of Evidence Level III, therapeutic study. See Guidelines for Authors for a complete description of levels of evidence.

\section{Introduction}

GCT of bone is a rare primary skeletal lesion accounting for approximately $5 \%$ of all primary bone tumors in adults. GCT has been described histologically as a benign neoplastic lesion consisting of three cell types: mononuclear histiocytic cells, multinucleated giant cells that resemble osteoclasts, and neoplastic stromal cells that are the main proliferating cell population [52]. On plain radiographs, the tumors appear as lytic lesions without matrix calcification (Fig. 1). Tumors arise in the metaepiphyseal region of long bones, predominantly in the distal femur and the proximal 
Fig. 1A-F (A) AP and (B) lateral views are shown of a GCT of the distal radius at diagnosis. (C) AP and (D) lateral radiographs obtained 6 months after intralesional surgery with polymethylmethacrylate filling are shown. (E) AP and (F) lateral radiographs obtained at the 3-year followup show no signs of recurrence.
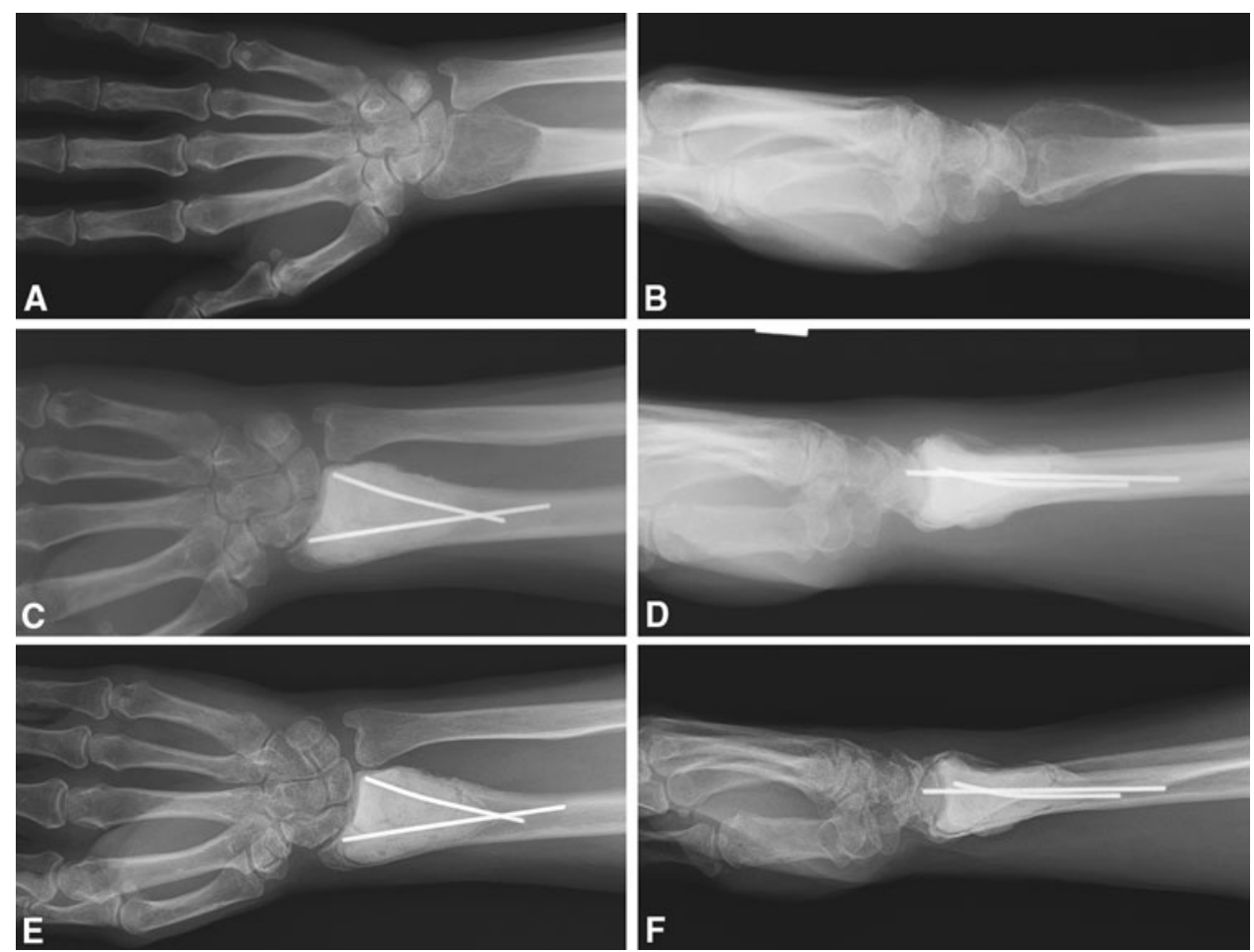

tibia, but they can occur in the entire skeleton [6]. Clinically, GCT presents as a benign but often aggressive lesion with a tendency toward local recurrence. Depending on the type of treatment and the local presentation of the tumor, recurrence rates range from $0 \%$ to $65 \%$ (Table 1) $[1,3,5$, $6,15,20,25,26,29,31,37,38,40,43,50]$.

Many surgeons treat GCT with intralesional curettage combined with high-speed burring to improve the thoroughness of tumor removal. It is the least invasive surgical option and usually allows preservation of the joint adjacent to the tumor. Intralesional curettage using bone graft as void filler and no additional adjuvants (such as cryotherapy or phenol) has been reported to result in recurrence rates between $12 \%$ and $65 \%[1,3,5,6,31,40$, $47,50]$. Recent studies indicated polymethylmethacrylate void filling and other adjuvants decrease the risk of local recurrence [1, 3, 22]. However, Blackley et al. [5] and Turcotte et al. [50] reported similar recurrence rates without the use of polymethylmethacrylate or other adjuvants. Wide resection is recommended when sacrificing the affected bone provides superior tumor control with minor functional impairment such as for tumors of the fibular head and the distal ulna [14, 16, 27]. Likewise, tumors with extensive bone destruction and large soft tissue mass or without the possibility to save the adjacent joint as a result of loss of the articular continuity are treated preferentially with wide resection [23, 31, 32, 51]. Various studies suggest wide resection is associated with a decreased risk of local recurrence as compared with intralesional curettage and may increase the recurrencefree survival rate to $84 \%$ to $100 \%[1,3,5,6,11,25,31$, 50]. However, wide resection is associated with higher rates of surgical complications [31] and often is accompanied by considerable functional impairment $[19,26$, 37]. In long bones, wide resection generally necessitates reconstruction with arthroplasties $[22,31,46]$ or massive allografts [46].

In 1986, we reported experience with 146 patients treated surgically for primary GCT [31]. In that report, recurrence rates after wide resection and intralesional excision were $7 \%$ and $34 \%$, respectively. The surgical margin was the only factor influencing the risk of local recurrence. None of the patients treated with intralesional curettage had received polymethylmethacrylate void filling. During the last 25 years, treatment strategies have been modified and polymethylmethacrylate has been used increasingly as a substitute for bone grafts.

We first determined the recurrence rates of GCT following wide resection and intralesional surgery and then asked (1) whether adjuvant therapy with polymethylmethacrylate void filling and/or local phenol application after intralesional curettage decreased the risk of local recurrence; (2) if disease-related factors such as tumor extension, pathologic fractures, and tumor localization or patient-related factors such as gender and age contributed to the risk of local recurrence; and (3) whether the development of benign pulmonary metastases was associated with local recurrence. 


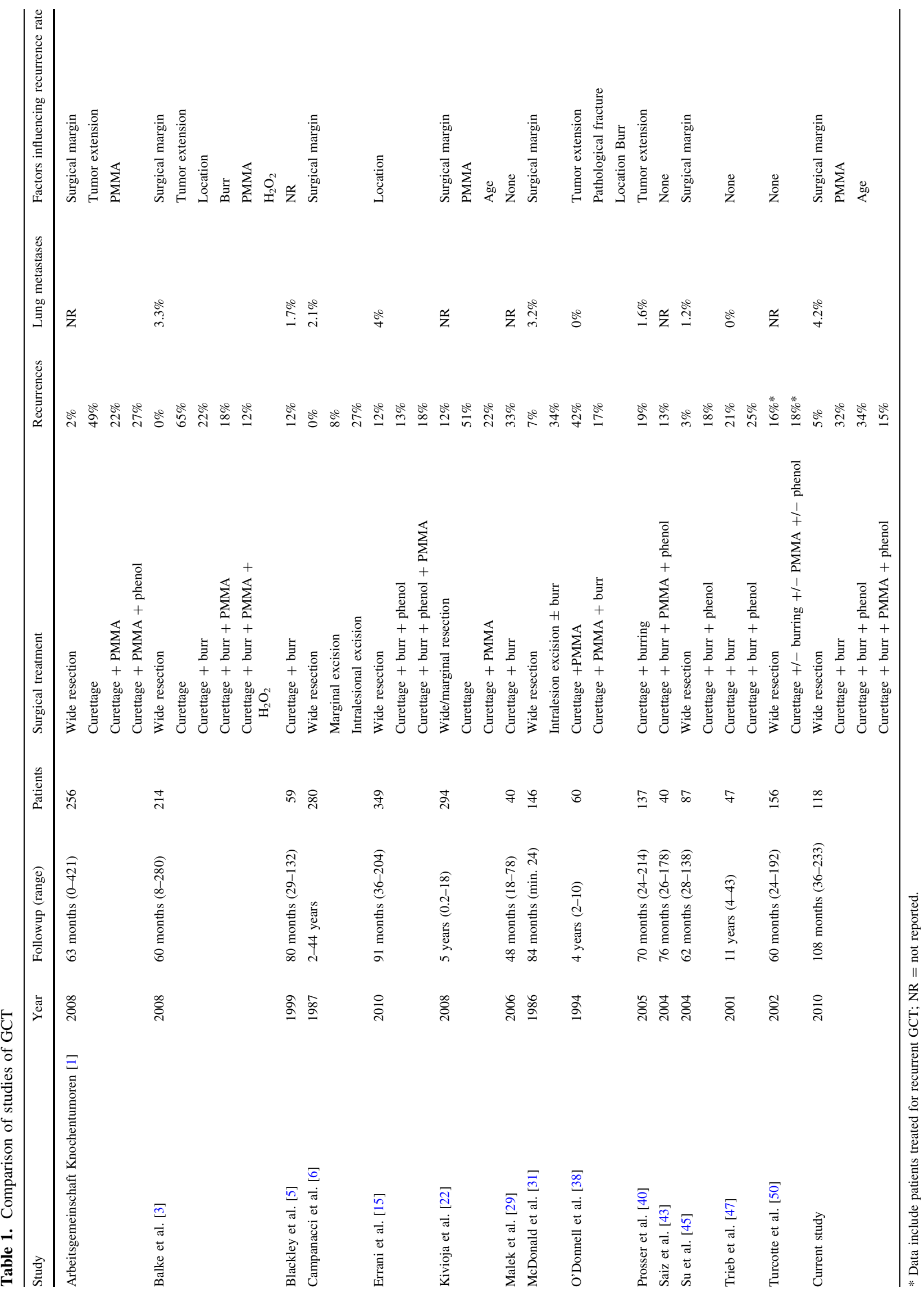




\section{Patients and Methods}

We retrospectively identified 215 patients diagnosed with histologically confirmed GCT of bone from January 1983 through July 2005. Twenty-six of these patients were referred for consultation only and did not receive any treatment at the Mayo Clinic. Sixty patients had received their initial treatment at an outside hospital and were surgically treated at our institution for local recurrence. To provide a more consistently treated group of patients, we excluded all patients referred to the Mayo Clinic subsequent to primary treatment at another hospital from the study. We therefore reviewed the medical records for all remaining 118 patients primarily treated at the Mayo Clinic. No patients were lost to followup. The patients were not recalled specifically for this study; all data were retrieved from medical records. The minimum followup was 36 months (mean, $108.4 \pm 43.7$ months; range, 36-233 months).

The lesions were graded according to Campanacci et al. [6] as Grade I, Grade II, or Grade III. Any pathologic fractures were noted. Intracompartmental or extracompartmental tumor growth was identified on the basis of preoperative imaging studies, including CT and MRI and on the basis of intraoperative findings. The compartmental extension was graded T1 or T2 according to the system of Enneking et al. [12, 13] and Wolf and Enneking [53]. All surgical specimens were reviewed by a board certified pathologist specializing in bone and soft tissue pathology and histologically classified as benign GCT.

Intralesional procedures were the most common surgical treatment $(\mathrm{n}=95$ or $81 \%$ ) (Table 2). Intralesional procedures included curettage and intralesional excisions, which were performed in the majority of tumors emerging from the spine and the sacrum. For intralesional procedures, a wide cortical window was created to observe the tumor cavity. The tumor tissue was removed with a curette. The borders of the tumor cavity then were ground away with a high-speed burr. The tumor cavity was inspected with a dental mirror or an endoscope to verify the removal of all tumor tissue. Eighty-nine percent phenol was applied in the borders of the cavity with cotton-tipped applicators and then neutralized with alcohol in 40 patients. Finally, the tumor cavity was packed carefully with autologous and/or allogenic bone grafts $(\mathrm{n}=54$ or $57 \%)$ or polymethylmethacrylate $(\mathrm{n}=41$ or $43 \%)$.

Procedures in which polymethylmethacrylate packing was combined with bone grafting were subsumed into polymethylmethacrylate treatment groups. Of the patients treated with intralesional surgery and polymethylmethacrylate void filling, 40 received additional local phenol and alcohol treatment. One patient was treated solely with polymethylmethacrylate and no additional adjuvants. Wide resections were performed in 21 (19\%) patients.
Table 2. Descriptive patient demographics and treatment data

\begin{tabular}{lcc}
\hline Parameter & Mean & SD \\
\hline $\begin{array}{l}\text { Patient age at diagnosis } \\
\quad \text { (years) }\end{array}$ & 35.4 & 15.8 \\
Time to recurrence (months) & 16.4 & 12.3 \\
Followup (months) & 108.3 & 43.8
\end{tabular}

\begin{tabular}{|c|c|c|}
\hline & Number & Percent \\
\hline \multicolumn{3}{|l|}{ Gender } \\
\hline Male & 53 & 45.3 \\
\hline Female & 65 & 54.7 \\
\hline \multicolumn{3}{|l|}{ Location } \\
\hline Distal femur & 29 & 24.6 \\
\hline Proximal femur & 4 & 3.4 \\
\hline Distal tibia & 6 & 5.1 \\
\hline Proximal tibia & 24 & 20.3 \\
\hline Proximal fibula & 3 & 2.5 \\
\hline Distal humerus & 1 & 0.8 \\
\hline Proximal humerus & 4 & 3.4 \\
\hline Distal radius & 12 & 10.2 \\
\hline Distal ulna & 2 & 1.7 \\
\hline Proximal ulna & 1 & 0.8 \\
\hline Hand & 4 & 3.4 \\
\hline Scapula & 1 & 0.8 \\
\hline Spine & 6 & 5.1 \\
\hline Sacrum & 13 & 11.0 \\
\hline Pelvis & 9 & 7.6 \\
\hline \multicolumn{3}{|l|}{ Grade (Campanacci) } \\
\hline Grade I & 5 & 4.2 \\
\hline Grade II & 46 & 39.0 \\
\hline Grade III & 67 & 56.8 \\
\hline \multicolumn{3}{|l|}{ Tumor extension } \\
\hline T1 & 62 & 52.5 \\
\hline $\mathrm{T} 2$ & 56 & 47.5 \\
\hline Pathologic fracture & 17 & 14.4 \\
\hline \multicolumn{3}{|l|}{ Treatment } \\
\hline Wide resection & 22 & 18.6 \\
\hline Intralesional surgery & 95 & 80.5 \\
\hline Nonsurgical treatment & 1 & 0.9 \\
\hline \multicolumn{3}{|l|}{ Adjuvants } \\
\hline No adjuvants (bone grafting) & 22 & 23.2 \\
\hline Bone grafting + phenol & 32 & 33.7 \\
\hline PMMA & 1 & 1.1 \\
\hline PMMA + phenol & 40 & 42.2 \\
\hline Recurrences-total & 25 & 21.4 \\
\hline Recurrences-bone & 21 & 17.9 \\
\hline Soft tissue implantations & 4 & 3.4 \\
\hline
\end{tabular}

Reconstructions after wide resections included arthroplasties $(n=7)$, structural allografts $(n=5)$, plate/screw reconstructions $(n=4)$, arthrodesis of the wrist $(n=3)$, 
and osteoarticular allografts $(\mathrm{n}=3)$. In three patients with GCTs of the sacrum, the surgery was combined with external beam radiation, in one patient before surgery and in two patients postoperatively. Amputations were not performed as primary procedures. One patient denying blood transfusion was treated nonsurgically as a result of the high surgical risk and received external beam radiation and tumor embolization instead. Treatment regimes did not differ among patients with different grades of disease. Eleven of $62 \mathrm{~T} 1$ tumors (18\%) and 11 of $55 \mathrm{~T} 2$ tumors (20\%) were treated with wide resection; nine of 50 patients (18\%) with Grades I/II disease and 13 of 67 patients (19\%) with Grade III disease were treated with wide resection.

Patients treated with resection or polymethylmethacrylate reconstructions were allowed to rapidly advance motion and weightbearing as their soft tissue envelopes healed because these reconstructions provided for immediate stability. Those treated with bone grafting procedures were kept none weightbearing with a brace or cast for 6 to 8 weeks followed by a gradual increase in activity as radiographs showed increased graft incorporation.

Routine followups were performed 3 and 6 months after surgery. Subsequently, followups were performed in 6-month intervals until 5 years after surgery. Afterward, checkups were not routinely scheduled. Routine followups included clinical examination and conventional radiographs in two planes. In case of suspicion for local recurrence, additional imaging including MRI and/or CT was performed. If patients were unable to return for followup, a physician in the patient's home community performed a similar examination and the radiographs were sent to our institution for evaluation.

All patients were treated primarily at our institution. Clinical files including operative surgical, radiology, and pathology reports were available for all 118 patients. For 29 patients, preoperative radiographs were taken by outside institutions and were not available. Written reports generated by our radiology department at the time of first consultation were available for these patients. Thus, tumor grading could be performed with available radiographs for 89 of 118 patients. For the other 29 patients, tumor grading was performed on the basis of the written radiology reports. With this approach, there were no missing data for statistical analysis.

Differences in the recurrence-free survival between the surgical procedures were calculated with the Kaplan-Meier survival; the log rank test of equality of survivor function was applied to compare treatment groups. Multivariate Cox regression was used to analyze the risk factors of local tumor recurrence. Test of factor interactions was performed to identify potential confounding variables. Statistical analysis was performed using SPSS Version 16 (SPSS Inc, Chicago, IL, USA).

\section{Results}

Twenty-five patients $(21 \%)$ had a local recurrence. One of the patients treated with wide resection had local recurrence. Twenty-four patients $(25 \%)$ treated with intralesional surgery experienced local recurrence. The mean interval between surgery and recurrence was $16.3 \pm$ 12.4 months (range, 4-50 months). In four patients treated with intralesional surgery, two or more instances of recurrence were observed. Repeat surgery achieved local control of the disease, as seen at followup in all patients. There was no identified late presentation of malignant transformation of GCT of bone.

Kaplan-Meier survival analysis (Fig. 2; Table 3) showed patients treated with wide resection had better $(p=0.036)$ recurrence-free survival as compared with the entire collective of patients treated with intralesional surgery (95\% versus $75 \%$ ). Among patients treated with intralesional surgery, those receiving polymethylmethacrylate void filling and local phenol treatment had better $(p=0.044)$ recurrence-free survival than patients receiving bone grafting with local phenol application (85\% versus 66\%). Local phenol use did not improve $(\mathrm{p}=0.804)$ the recurrence-free survival for patients treated with bone grafting (66\% [bone grafting plus phenol] versus $68 \%$ [bone grafting only]).

Analyzing the hazard ratios associated with recurrence, we found intralesional surgery had a greater risk

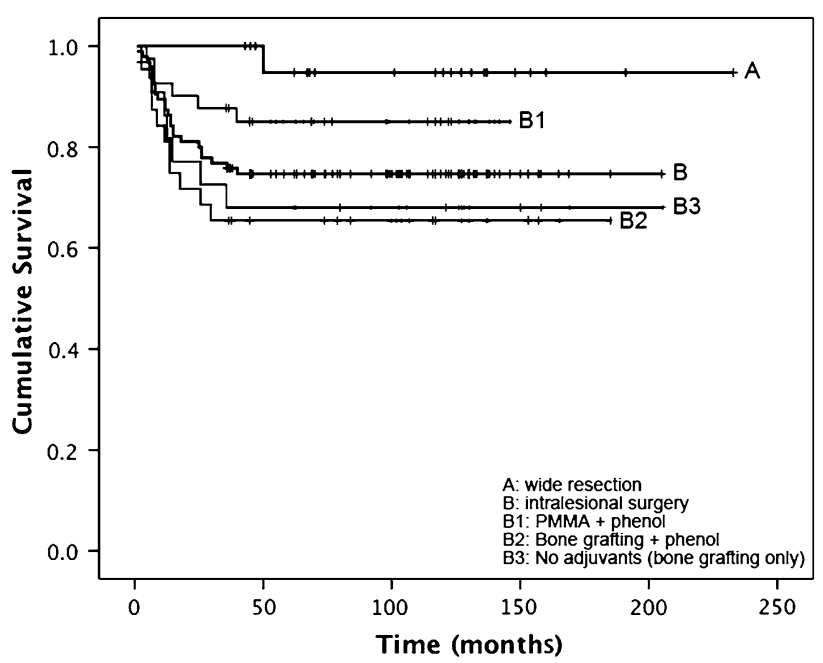

Fig. 2 Recurrence-free survival for patients with primary giant cell tumor (GCT) treated with wide resection (A) and intralesional surgery (B) is shown. Treatment subgroups for patients were intralesional surgery included the use of polymethylmethacrylate (PMMA) and phenol (B1), the use of bone grafting and phenol (B2), and intralesional surgery without adjuvants (B3). The estimated cumulative recurrence free survival ( $95 \%$ confidence interval) rates were 0.947 (0.847-0.999) for Group A, 0.747 (0.659-0.835) for Group B, $0.851(0.741-0.961)$ for Group B1, $0.656(0.491-0.821)$ for Group B2, and $0.682(0.488-0.876)$ Group B3. 
Table 3. Kaplan-Meier survival analysis of recurrence-free survival 10 years after surgery

\begin{tabular}{llllrll}
\hline Surgical treatment & $\begin{array}{l}\text { Recurrence-free } \\
\text { survival }\end{array}$ & $\begin{array}{l}\text { Standard } \\
\text { error }\end{array}$ & $\begin{array}{l}\text { Mean recurrence-free } \\
\text { survival (months) }\end{array}$ & $\begin{array}{l}\text { 95\% confidence } \\
\text { interval }\end{array}$ & $\begin{array}{l}\mathrm{p} \text { (versus wide } \\
\text { resection) }\end{array}$ & $\begin{array}{l}\mathrm{p} \text { (versus } \\
\text { PMMA }+ \text { phenol) }\end{array}$ \\
\hline Wide resection & 0.955 & 0.051 & 116 & $109-123$ & - & - \\
Intralesional surgery & 0.747 & 0.045 & 93 & $84-103$ & 0.036 & - \\
PMMA + phenol & 0.854 & 0.056 & 105 & $93-116$ & 0.209 & - \\
Bone grafting + phenol & 0.656 & 0.084 & 83 & $66-101$ & 0.009 & 0.044 \\
No adjuvants (bone grafting) & 0.682 & 0.099 & 87 & $67-107$ & 0.018 & 0.107 \\
\hline
\end{tabular}

( $\mathrm{p}=0.042)$ of local recurrence compared with wide resection (hazard ratio, 8.71) (Table 4). Among patients undergoing intralesional procedures, those treated with polymethylmethacrylate and local phenol application had a smaller risk ( $\mathrm{p}=0.030$ ) for local recurrence than patients treated with bone grafting and local phenol application (hazard ratio, 3.232). For patients treated with bone grafting, additional phenol application did not decrease the risk $(\mathrm{p}=0.799)$ of recurrence (hazard ratio, 1.129).

Among the disease-related and demographic factors analyzed for their impact on recurrence, only age at the time of diagnosis was associated with risk $(p=0.019)$ of local recurrence. Subgroup analysis revealed patients 25 years and younger at diagnosis had the greatest hazard of local recurrence. Age at diagnosis was an independent risk factor for recurrence regardless of the status of the disease and the chosen treatment. The increased risk of recurrence in young patients was not biased by other variables such as type of surgery $(p=0.089)$, adjuvants $(\mathrm{p}=0.22)$, tumor grade $(\mathrm{p}=0.67)$, tumor extension $(\mathrm{p}=0.72)$, and pathologic fractures $(\mathrm{p}=0.63)$.

Pulmonary metastases occurred in five patients. In three, pulmonary metastases were associated with recurrent disease; two patients had pulmonary metastases develop without local recurrence. Treatment of pulmonary metastases consisted of a multidisciplinary approach, including wedge resection, chemotherapy, and radiotherapy. With this approach, a status of no evidence of disease or stable disease was achieved in two and three patients, respectively.

\section{Discussion}

Intralesional curettage has been established as the preferred treatment for most GCTs. Wide resection is reserved for tumors with extensive destruction, impossible joint salvage, and when expendable bones (ie, fibular head or distal ulna) are affected [14, 16, 23, 27, 31, 32, 51]. We analyzed the recurrence-free survival after treatment of GCT with an emphasis on the impact of surgical approach, adjuvant therapy, tumor presentation, and demographic factors on the risk of recurrence in 118 patients.
Although this investigation benefits from a large group of patients with extended followup, there are several clear limitations to this retrospective study. First, data were gathered from clinical files, and patients were not contacted to assess ultimate outcomes. Second, although the total sample size is relatively large, the number of patients in each treatment group becomes relatively small and limits our ability to draw conclusions. Finally, we limited patients to those treated primarily at our institution. However, this study design did allow us to analyze a large cohort of patients consistently treated. We also had access to a complete set of data for the patients included in this study.

Similar to previous reports $[1,3,6,15,22,31,45,46]$, we found wide resection was associated with a lower risk of recurrence than intralesional surgery. When intralesional procedures are performed, local adjuvants (polymethylmethacrylate, phenol, hydrogen peroxide, and cryotherapy) have been reported to improve tumor control $[1,3,5,11$, 28]. We found polymethylmethacrylate use decreased the risk of local recurrence. Similar risk reductions have been observed by others [1, 3, 22], and have been attributed to thermal and toxic effects on tumor cells [33, 36]. Additionally, polymethylmethacrylate may decrease the risk of collapse and allow for more aggressive tumor removal as a result of its favorable mechanical properties. Considering the importance of thorough tumor removal, this capacity may overshadow the effects of heat-mediated tumor effects, a suggestion that also was made by Ghert et al. [18].

Phenol is a commonly used adjuvant for GCT treatment. Phenol induces tumor necrosis [24, 41] with few adverse effects [35, 47]. However, tissue penetration is poor and limits tumor necrosis to superficial cell layers [24]. Yun et al. found a negligible necrotizing effect of phenol and discounted it as an adjuvant after curettage of bone tumors [54]. Others also have reported little effect of phenol on recurrence [1, 47, 49]. However, Durr et al. did report decreased local recurrence with the use of phenol [11]. In the current study, we did not find any effect of adjuvant phenol treatment on GCT recurrence.

Age at diagnosis independently predicted recurrence regardless of the status of the disease and the aggressiveness 
Table 4. Hazard of recurrence in association with potential risk factors

\begin{tabular}{|c|c|c|c|c|}
\hline \multirow[t]{2}{*}{ Factor } & \multirow[t]{2}{*}{ Hazard } & \multicolumn{2}{|c|}{$\begin{array}{l}95 \% \text { confidence } \\
\text { interval for }\end{array}$} & \multirow[t]{2}{*}{$\mathrm{p}$} \\
\hline & & Lower & Upper & \\
\hline \multicolumn{5}{|l|}{ Gender } \\
\hline Male & 1.000 & & & \\
\hline Female & 0.825 & 0.373 & 1.825 & 0.635 \\
\hline \multicolumn{5}{|l|}{ Age at diagnosis } \\
\hline$\leq 25$ years & 1.000 & & & \\
\hline $26-50$ years & 0.519 & 0.226 & 1.195 & 0.123 \\
\hline$\geq 51$ years & 0.190 & 0.043 & 0.844 & 0.029 \\
\hline \multicolumn{5}{|l|}{ Location } \\
\hline Distal femur & 1.000 & & & \\
\hline Proximal femur & 0.000 & 0.000 & & 0.987 \\
\hline Distal tibia & 1.744 & 0.340 & 8.948 & 0.505 \\
\hline Proximal tibia & 0.618 & 0.163 & 2.341 & 0.479 \\
\hline Proximal fibula & 4.897 & 0.505 & 47.439 & 0.170 \\
\hline Distal humerus & 0.000 & 0.000 & & 0.994 \\
\hline Proximal humerus & 3.724 & 0.635 & 21.859 & 0.145 \\
\hline Distal radius & 0.000 & 0.000 & & 0.995 \\
\hline Distal ulna & 1.032 & 0.194 & 5.481 & 0.970 \\
\hline Proximal ulna & 0.000 & 0.000 & & 0.992 \\
\hline Hand & 4.199 & 0.779 & 22.635 & 0.095 \\
\hline Scapula & 0.000 & 0.000 & & 0.994 \\
\hline Spine & 1.375 & 0.250 & 7.546 & 0.714 \\
\hline Sacrum & 0.594 & 0.103 & 3.410 & 0.559 \\
\hline Pelvis & 1.100 & 0.203 & 5.969 & 0.912 \\
\hline \multicolumn{5}{|l|}{ Grade (Campanacci) } \\
\hline Grade I & 1.000 & & & \\
\hline Grade II & 0.679 & 0.072 & 6.438 & 0.736 \\
\hline Grade III & 1.152 & 0.103 & 12.944 & 0.909 \\
\hline \multicolumn{5}{|l|}{ Tumor extension } \\
\hline $\mathrm{T} 1$ & 1.000 & & & \\
\hline $\mathrm{T} 2$ & 0.833 & 0.205 & 3.380 & 0.789 \\
\hline \multicolumn{5}{|l|}{ Pathologic fracture } \\
\hline No & 1.000 & & & \\
\hline Yes & 0.698 & 0.138 & 3.545 & 0.665 \\
\hline \multicolumn{5}{|l|}{ Surgery } \\
\hline Wide resection & 1.000 & & & \\
\hline Intralesional surgery & 8.711 & 1.063 & 71.415 & 0.042 \\
\hline \multicolumn{5}{|l|}{ Adjuvants } \\
\hline PMMA + phenol & 1.000 & & & \\
\hline $\begin{array}{l}\text { Bone grafting }+ \\
\text { phenol }\end{array}$ & 3.232 & 1.122 & 9.310 & 0.030 \\
\hline $\begin{array}{l}\text { No adjuvants } \\
\text { (bone grafting) }\end{array}$ & 2.862 & 0.908 & 9.022 & 0.073 \\
\hline
\end{tabular}

of the chosen treatment: recurrence rate decreased as the patient's age increased. The greater risk of young patients having recurrence develop has been reported [22] and may be associated with increased bone turnover in young people [21, 34]. This hypothesis is supported by studies showing inhibition of bone turnover with bisphosphonates reduced the risk of recurrence of GCT [7, 9, 17, 48].

Other demographic and disease-related variables (gender, location, tumor grade, soft tissue extension, and pathologic fracture) had no influence on local recurrence in our patients included in this study. Previous studies also have shown that gender, location, and tumor grade did not influence recurrence $[1,3,43,50]$. The prognostic relevance of soft tissue expansion and pathologic fractures is controversial $[1,3,15,22,31,38,40,50]$. Becker et al. found the prevalence of soft tissue extension influenced the risk of local recurrence [1] and O'Donnell et al. reported pathologic fractures were associated with an increased recurrence rate [38]. The aggressiveness of the treatment should be considered when interpreting the correlation of soft tissue expansion or pathologic fractures and local recurrence. In the current study, wide resection was performed in $18 \%$ and $20 \%$ of $\mathrm{T} 1$ and $\mathrm{T} 2$ tumors, respectively, indicating the recurrence rates of $\mathrm{T} 1$ and $\mathrm{T} 2$ tumors were not biased by differences in the aggressiveness of surgical treatment. In tumors with and without pathologic fractures, wide resections were performed in $47 \%$ and $14 \%$, respectively. Thus, patients with pathologic fractures more commonly received resections. In this retrospective study, this may underestimate the risk of recurrence in patients with pathologic fractures.

The rate of pulmonary metastases in our study patients was $4 \%$, similar to previous reports reporting ranges from $0 \%$ to $4 \%[3,4,8,10,15,20,30,39,42,44,49]$. Two of five patients were diagnosed with metastases at presentation, showing patients with GCT are at risk for development of synchronous pulmonary metastases. Although GCT is classified as a benign lesion [52], few patients develop progressive lung metastases with poor outcomes [2, 6, 44]. Our treatment approach, including wedge resections, radiotherapy, and chemotherapy, achieved disease eradication or stability in all patients with pulmonary metastases.

It is difficult to quantify the real morbidity (physical and emotional) of patients who experience recurrence and require repeat surgery. Based on the results of this study, we recommend intralesional surgery for treating most GCTs; the selection of bone graft versus polymethylmethacrylate remains individualized. Because young age is a risk factor for local recurrence, we favor the use of polymethylmethacrylate in young patients as the best way to minimize recurrence and preserve the native joint. Similarly, when little bone stock remains or for patients with questionable compliance for a limited weightbearing rehabilitation, methylmethacrylate is favored for its immediate stability. Local phenol treatment did not reduce 
the risk of recurrence, and we no longer consider phenol an effective adjuvant. Finally, patients with adverse presentations or an adamant desire for one surgery may be best suited for resection at the time of presentation. However, because the treatment of pulmonary metastases in patients with GCT usually controls the disease and metastases may occur independent of recurrence, we believe the potential risk for development of pulmonary metastases should not by itself create an indication for wide resection of primary tumors.

\section{References}

1. Arbeitsgemeinschaft Knochentumoren. Local recurrence of giant cell tumor of bone after intralesional treatment with and without adjuvant therapy. J Bone Joint Surg Am. 2008;90:1060-1067.

2. Balke M, Ahrens H, Streitbuerger A, Koehler G, Winkelmann W, Gosheger G, Hardes J. Treatment options for recurrent giant cell tumors of bone. J Cancer Res Clin Oncol. 2009;135:149-158.

3. Balke M, Schremper L, Gebert C, Ahrens H, Streitbuerger A, Koehler G, Hardes J, Gosheger G. Giant cell tumor of bone: treatment and outcome of 214 cases. J Cancer Res Clin Oncol. 2008;134:969-978.

4. Bertoni F, Present D, Sudanese A, Baldini N, Bacchini P, Campanacci M. Giant-cell tumor of bone with pulmonary metastases: six case reports and a review of the literature. Clin Orthop Relat Res. 1988;237:275-285.

5. Blackley HR, Wunder JS, Davis AM, White LM, Kandel R, Bell RS. Treatment of giant-cell tumors of long bones with curettage and bone-grafting. J Bone Joint Surg Am. 1999;81:811-820.

6. Campanacci M, Baldini N, Boriani S, Sudanese A. Giant-cell tumor of bone. J Bone Joint Surg Am. 1987;69:106-114.

7. Chang SS, Suratwala SJ, Jung KM, Doppelt JD, Zhang HZ, Blaine TA, Kim TW, Winchester RJ, Lee FY. Bisphosphonates may reduce recurrence in giant cell tumor by inducing apoptosis. Clin Orthop Relat Res. 2004;426:103-109.

8. Cheng JC, Johnston JO. Giant cell tumor of bone: prognosis and treatment of pulmonary metastases. Clin Orthop Relat Res. 1997; 338:205-214.

9. Cheng YY, Huang L, Lee KM, Xu JK, Zheng MH, Kumta SM. Bisphosphonates induce apoptosis of stromal tumor cells in giant cell tumor of bone. Calcif Tissue Int. 2004;75:71-77.

10. Dominkus M, Ruggieri P, Bertoni F, Briccoli A, Picci P, Rocca M, Mercuri M. Histologically verified lung metastases in benign giant cell tumours: 14 cases from a single institution. Int Orthop. 2006;30:499-504.

11. Durr HR, Maier M, Jansson V, Baur A, Refior HJ. Phenol as an adjuvant for local control in the treatment of giant cell tumour of the bone. Eur J Surg Oncol. 1999;25:610-618.

12. Enneking WF. A system of staging musculoskeletal neoplasms. Clin Orthop Relat Res. 1986;204:9-24.

13. Enneking WF, Spanier SS, Goodman MA. A system for the surgical staging of musculoskeletal sarcoma. Clin Orthop Relat Res. 1980;103:106-120.

14. Erler K, Demiralp B, Ozdemir MT, Basbozkurt M. Treatment of proximal fibular tumors with en bloc resection. Knee. 2004; 11:489-496.

15. Errani C, Ruggieri P, Asenzio MA, Toscano A, Colangeli S, Rimondi E, Rossi G, Longhi A, Mercuri M. Giant cell tumor of the extremity: a review of 349 cases from a single institution. Cancer Treat Rev. 2010;36:1-7.
16. Faezypour H, Davis AM, Griffin AM, Bell RS. Giant cell tumor of the proximal fibula: surgical management. J Surg Oncol. 1996;61:34-37.

17. Fujimoto N, Nakagawa K, Seichi A, Terahara A, Tago M, Aoki Y, Hosoi Y, Ohtomo K. A new bisphosphonate treatment option for giant cell tumors. Oncol Rep. 2001;8:643-647.

18. Ghert MA, Rizzo M, Harrelson JM, Scully SP. Giant-cell tumor of the appendicular skeleton. Clin Orthop Relat Res. 2002;400: 201-210.

19. Gitelis S, Mallin BA, Piasecki P, Turner F. Intralesional excision compared with en bloc resection for giant-cell tumors of bone. J Bone Joint Surg Am. 1993;75:1648-1655.

20. Goldenberg RR, Campbell CJ, Bonfiglio M. Giant-cell tumor of bone: an analysis of two hundred and eighteen cases. J Bone Joint Surg Am. 1970;52:619-664.

21. Kelly PJ, Pocock NA, Sambrook PN, Eisman JA. Age and menopause-related changes in indices of bone turnover. J Clin Endocrinol Metab. 1989;69:1160-1165.

22. Kivioja AH, Blomqvist C, Hietaniemi K, Trovik C, Walloe A, Bauer HC, Jorgensen PH, Bergh P, Folleras G. Cement is recommended in intralesional surgery of giant cell tumors: a Scandinavian Sarcoma Group study of 294 patients followed for a median time of 5 years. Acta Orthop. 2008;79:86-93.

23. Labs K, Perka C, Schmidt RG. Treatment of stages 2 and 3 giantcell tumor. Arch Orthop Trauma Surg. 2001;121:83-86.

24. Lack W, Lang S, Brand G. Necrotizing effect of phenol on normal tissues and on tumors: a study on postoperative and cadaver specimens. Acta Orthop Scand. 1994;65:351-354.

25. Lausten GS, Jensen PK, Schiodt T, Lund B. Local recurrences in giant cell tumour of bone: long-term follow up of 31 cases. Int Orthop. 1996;20:172-176.

26. Liu HS, Wang JW. Treatment of giant cell tumor of bone: a comparison of local curettage and wide resection. Changgeng $Y i$ Xие Za Zhi. 1998;21:37-43.

27. Malawer MM. Surgical management of aggressive and malignant tumors of the proximal fibula. Clin Orthop Relat Res. 1984;186:172-181.

28. Malawer MM, Bickels J, Meller I, Buch RG, Henshaw RM, Kollender Y. Cryosurgery in the treatment of giant cell tumor: a long-term followup study. Clin Orthop Relat Res. 1999;359: $176-188$

29. Malek F, Krueger P, Hatmi ZN, Malayeri AA, Faezipour H, O'Donnell RJ. Local control of long bone giant cell tumour using curettage, burring and bone grafting without adjuvant therapy. Int Orthop. 2006;30:495-498.

30. Masui F, Ushigome S, Fujii K. Giant cell tumor of bone: a clinicopathologic study of prognostic factors. Pathol Int. 1998; 48:723-729.

31. McDonald DJ, Sim FH, McLeod RA, Dahlin DC. Giant-cell tumor of bone. J Bone Joint Surg Am. 1986;68:235-242.

32. Mendenhall WM, Zlotecki RA, Scarborough MT, Gibbs CP, Mendenhall NP. Giant cell tumor of bone. Am J Clin Oncol. 2006;29:96-99.

33. Mjoberg B, Pettersson H, Rosenqvist R, Rydholm A. Bone cement, thermal injury and the radiolucent zone. Acta Orthop Scand. 1984;55:597-600.

34. Mora S, Prinster C, Proverbio MC, Bellini A, de Poli SC, Weber G, Abbiati G, Chiumello G. Urinary markers of bone turnover in healthy children and adolescents: age-related changes and effect of puberty. Calcif Tissue Int. 1998;63:369-374.

35. Muramatsu K, Ihara K, Taguchi T. Treatment of giant cell tumor of long bones: clinical outcome and reconstructive strategy for lower and upper limbs. Orthopedics. 2009;32:491.

36. Nelson DA, Barker ME, Hamlin BH. Thermal effects of acrylic cementation at bone tumour sites. Int J Hyperthermia. 1997; $13: 287-306$. 
37. Oda Y, Miura H, Tsuneyoshi M, Iwamoto Y. Giant cell tumor of bone: oncological and functional results of long-term follow-up. Jpn J Clin Oncol. 1998;28:323-328.

38. O'Donnell RJ, Springfield DS, Motwani HK, Ready JE, Gebhardt MC, Mankin HJ. Recurrence of giant-cell tumors of the long bones after curettage and packing with cement. J Bone Joint Surg Am. 1994;76:1827-1833.

39. Osaka S, Toriyama M, Taira K, Sano S, Saotome K. Analysis of giant cell tumor of bone with pulmonary metastases. Clin Orthop Relat Res. 1997;335:253-261.

40. Prosser GH, Baloch KG, Tillman RM, Carter SR, Grimer RJ. Does curettage without adjuvant therapy provide low recurrence rates in giant-cell tumors of bone? Clin Orthop Relat Res. 2005;435:211-218.

41. Quint U, Vanhofer U, Harstrick A, Muller RT. Cytotoxicity of phenol to musculoskeletal tumours. J Bone Joint Surg Br. 1996; 78:984-985.

42. Rock MG, Pritchard DJ, Unni KK. Metastases from histologically benign giant-cell tumor of bone. J Bone Joint Surg Am. 1984; 66:269-274.

43. Saiz P, Virkus W, Piasecki P, Templeton A, Shott S, Gitelis S. Results of giant cell tumor of bone treated with intralesional excision. Clin Orthop Relat Res. 2004;424:221-226.

44. Siebenrock KA, Unni KK, Rock MG. Giant-cell tumour of bone metastasising to the lungs: a long-term follow-up. J Bone Joint Surg Br. 1998;80:43-47.

45. Su YP, Chen WM, Chen TH. Giant-cell tumors of bone: an analysis of 87 cases. Int Orthop. 2004;28:239-243.
46. Sung HW, Kuo DP, Shu WP, Chai YB, Liu CC, Li SM. Giantcell tumor of bone: analysis of two hundred and eight cases in Chinese patients. J Bone Joint Surg Am. 1982;64:755-761.

47. Trieb K, Bitzan P, Lang S, Dominkus M, Kotz R. Recurrence of curetted and bone-grafted giant-cell tumours with and without adjuvant phenol therapy. Eur J Surg Oncol. 2001;27:200-202.

48. Tse LF, Wong KC, Kumta SM, Huang L, Chow TC, Griffith JF. Bisphosphonates reduce local recurrence in extremity giant cell tumor of bone: a case-control study. Bone. 2008;42:68-73.

49. Tubbs WS, Brown LR, Beabout JW, Rock MG, Unni KK. Benign giant-cell tumor of bone with pulmonary metastases: clinical findings and radiologic appearance of metastases in 13 cases. AJR Am J Roentgenol. 1992;158:331-334.

50. Turcotte RE, Wunder JS, Isler MH, Bell RS, Schachar N, Masri BA, Moreau G, Davis AM; Canadian Sarcoma Group. Giant cell tumor of long bone: a Canadian Sarcoma Group study. Clin Orthop Relat Res. 2002;397:248-258.

51. Ward WG Sr, Li G III. Customized treatment algorithm for giant cell tumor of bone: report of a series. Clin Orthop Relat Res. 2002;397:259-270.

52. Werner M. Giant cell tumour of bone: morphological, biological and histogenetical aspects. Int Orthop. 2006;30:484-489.

53. Wolf RE, Enneking WF. The staging and surgery of musculoskeletal neoplasms. Orthop Clin North Am. 1996;27:473-481.

54. Yun YH, Kim NH, Han DY, Kang ES. An investigation of bone necrosis and healing after cryosurgery, phenol cautery or packing with bone cement of defects in the dog femur. Int Orthop. 1993;17:176-183. 